\title{
A SITUAÇÃO DAS AMÉRICAS: DEMOCRACIA, CAPITAL SOCIAL E EMPODERAMENTO
}

Os chamados países emergentes da América Latina, nas últimas duas décadas, têm sofrido transformações significativas tanto no campo formal quanto no que diz respeito a algumas conquistas sociais. Do ponto de vista poliárquico, as novas democracias latino-americanas têm sido consideradas pelas Nações Unidas como democracias consolidadas: temos eleições periódicas, existência de partidos políticos e, sobretudo, o reconhecimento, no que diz respeito às eleições, da legitimidade dos vencedores. Entretanto, do ponto de vista da construção de uma cidadania ativa constata-se, segundo pesquisas de opinião, como o Latinobarómetro, o aumento da desconfiança interpessoal e em relação às instituições políticas, por parte das pessoas.

Neste contexto, vivemos atualmente uma assimetria entre procedimentos democráticos eficientes e o aumento da desigualdade social e da pobreza. Nestas circunstâncias, têm surgido paradigmas alternativos que buscam incorporar à dimensão institucional da análise democrática elementos de natureza substantiva, sendo os mais importantes: a construção da cidadania, a abertura de espaços políticos para a população e as novas formas de agregar e articular interesses da população em relação ao Estado. Alguns dos conceitos mais significativos desta nova perspectiva de análise são: desenvolvimento sustentável, capital social e empoderamento. Tais dispositivos de participação buscam superar as formas tradicionais de fazer política, caracterizadas pelo clientelismo, personalismo e a corrupção.

Neste cenário, torna-se relevante examinar de que forma novos formatos de ação coletiva, que funcionem paralelamente aos mecanismos de mediação política tradicional (partidos políticos), podem fortalecer a cidadania e, consequentemente, a qualidade democrática. Reflexões sobre estas questões fizeram parte da agenda do Seminário Internacional Desenvolvimento Sustentável e Capital Social na América Latina, no qual foram discutidos resultados da pesquisa Capital Social e Desenvolvimento Sustentável na Promoção da Cidadania e da Qualidade de Vida: Estudo Comparado entre Cidades do Brasil, Chile e Uruguai, coordenada por Marcello Baquero, responsável pelo NUPESAL (Núcleo de Pesquisa sobre a América Latina) do Instituto de Filosofia e Ciências Humanas da Universidade Federal do Rio Grande do Sul, que resultaram na publicação do projeto piloto de edição da Revista Debates, publicado em 2005.

A Revista Debates foi publicada inicialmente pelo Núcleo de Pesquisa sobre a América Latina, em versão impressa, sendo hoje a responsabilidade de suas edições, impressa e digital, compartilhada entre o NUPESAL e o Programa de Pós-Graduação em Ciência Política da UFRGS, que comemora, este ano, os 40 anos de sua fundação. Com crescente número de submissões nos últimos semestres, a Revista Debates deixa de ser semestral e passa, a partir desta edição, a ser uma publicação quadrimestral. 
Decorrente do Seminário, nos últimos anos os pesquisadores envolvidos têm avançado na compreensão da construção democrática nesta região com base nos conceitos referidos. Fruto de um esforço colaborativo, a pesquisa foi replicada em 2009, em Santiago do Chile, e em 2010, em Porto Alegre. Em 2011, dando continuidade a esforços cooperativos, realizou-se um conjunto de palestras e de encontros de trabalho com o objetivo de ampliar o escopo da compreensão destes conceitos com professores dos Estados Unidos e do México. Fruto dessas discussões, o Conselho Editorial da Revista Debates deliberou e decidiu publicar um dossiê intitulado $A$ Situação das Américas: Democracia, Capital Social e Empoderamento, comemorativo do lançamento do projeto piloto (que obteve impressão restrita).

O dossiê está organizado em três partes. A primeira é de natureza conceitual, com estudos de caso. A segunda, apresenta textos relacionados à participação. Na terceira parte incluímos dois artigos que examinam os conceitos, objetos desse dossiê, para o caso norte-americano.

Esperamos que os artigos ora reunidos nesta edição possam auxiliar não só acadêmicos, mas também gestores públicos, subsidiando decisões e políticas públicas, a fim de contribuir para a melhoria da democracia e, consequentemente, para a melhoria da qualidade de vida da população das Américas.

Marcello Baquero

Rodrigo Stumpf González

Aaron Schneider

Bianca de Freitas Linhares

Organizadores 